Article

\title{
Air-Travelers' Perceptions of Service Quality during the COVID-19 Pandemic: Evidence from Tripadvisor Sites
}

\author{
Deniz Sulu ${ }^{1}$, Huseyin Arasli ${ }^{2, *(1)}$ and Mehmet Bahri Saydam ${ }^{3}(\mathbb{D}$ \\ 1 Department of Civil Aviation Management, Anadolu Bil Vocational School, Istanbul Aydin University, \\ İstanbul 34295, Turkey; denizsulu@aydin.edu.tr \\ 2 Norwegian School of Hotel Management, University of Stavanger, 4036 Stavanger, Norway \\ 3 Faculty of Tourism, Eastern Mediterranean University, TRNC, Via Mersin 10, Gazimagusa 99628, Turkey; \\ mehmet.saydam@emu.edu.tr \\ * Correspondence: huseyin.arasli@uis.no
}

check for updates

Citation: Sulu, D.; Arasli, H.; Saydam, M.B. Air-Travelers' Perceptions of Service Quality during the COVID-19 Pandemic: Evidence from Tripadvisor Sites. Sustainability 2022, 14, 435. https://doi.org/ $10.3390 /$ su14010435

Academic Editor: Erdogan Koc

Received: 4 December 2021

Accepted: 28 December 2021

Published: 31 December 2021

Publisher's Note: MDPI stays neutral with regard to jurisdictional claims in published maps and institutional affiliations.

Copyright: (c) 2021 by the authors. Licensee MDPI, Basel, Switzerland. This article is an open access article distributed under the terms and conditions of the Creative Commons Attribution (CC BY) license (https:/ / creativecommons.org/licenses/by/ $4.0 /)$.

\begin{abstract}
The COVID-19 pandemic has impacted both healthcare and the economy on a global scale. This pandemic has changed consumer habits and behaviors significantly, primarily because of confinement-related issues. While numerous research has been undertaken to study customer satisfaction using surveys and online passenger ratings, the effect of COVID-19 on passenger satisfaction has not been explored. It is vital to assess satisfaction indicators gathered from online consumer reviews to ascertain consumers' preferences for airline services during the COVID-19 pandemic. The goal of this study is to determine the primary themes that emerged from airline travelers' internet reviews during the COVID-19 outbreak. Additionally, it attempts to determine which of these themes relate to higher and lower passenger satisfaction. The article uses qualitative (i.e., narratives) analyses to examine the main components of passengers' subjective experiences of the airline. Data are represented by passenger reviews posted on the TripAdvisor website. The analyses revealed ten themes in descriptions of airline travel experiences. These include "flight", "service", "staff", "food", "check-in", "cancellation", “COVID-19", "airport", "class", and "luggage”. Dissatisfying concepts are linked with the "cancellation", "check-in", "refund", and "airport" concepts.
\end{abstract}

Keywords: COVID-19 outbreak; online passengers' reviews; passengers' satisfaction; Leximancer; airline; TripAdvisor

\section{Introduction}

The airline industry's fierce competitiveness needs efficient customer relations management both online and offline in order to retain passenger satisfaction and so generate future revenue. Customer feedback in particular is vital since it acts as a catalyst for corporate growth and performance as well as for the enhancement of the passenger experience and the development of novel products and services. Hence, airlines must satisfy their passengers and convert this contentment into behavioral commitment in order to remain competitive [1].

Online reviews, the most prevalent type of user-generated content (UGC), have enabled travelers to express their preferences for tourism services and share their tourism experiences [1-3]. Online reviews are frequently used to examine passenger satisfaction in tourist and hospitality environments $[4,5]$. Numerous studies on customer satisfaction have been done focusing on quantitative methods in the hospitality industry [1]. However, it is critical to employ advanced methods when extracting satisfaction dimensions from online evaluations [6]. This will help researchers to derive important meaning from passenger remarks, hence aiding decision making and enhancing service quality [7]. As a result, numerous machine learning algorithms have been applied to tourism and hospitality data analysis $[6,8]$. These approaches demonstrate that machine learning can be used efficiently to deduce the aspects of an individual's experience and feeling from vast datasets [6]. 
Indeed, in contrast to survey-based research using statistical techniques, machine learning techniques may automatically discover consumer preferences from large social datasets in the form of online customer evaluations [9].

The World Health Organization (WHO) labeled the latest coronavirus (COVID-19) outbreak a worldwide pandemic following an evaluation of the pandemic's worrisome levels of spread and severity. As a result, thousands of people were later forced to postpone vacations. The pandemic of COVID-19 has resulted in significant global changes in healthcare and the economy [10-12]. This pandemic has resulted in significant changes in consumer habits and behavior, mostly because of confinement-related problems [13]. Numerous major vacation locations have been impacted by the COVID-19 pandemic. Due to the pandemic, travelers who had planned to travel overseas are canceling or postponing their vacations [6].

The COVID-19 pandemic has outstripped all previous pandemics, spreading to over 200 nations, and has aided in its spread by the aviation sector [14]. The COVID-19 pandemic has wreaked havoc on the world's airline sector on a scale never seen before $[15,16]$. From an aviation perspective, although the worldwide aviation sector was flourishing, the COVID-19 pandemic impacted it severely. The loss in global commercial aviation profit is expected to reach 51.8 billion U.S. dollars in 2021, after a loss of 137.7 billion U.S. dollars in 2020. The COVID-19 pandemic has developed into the most dangerous to the airline sector in history [17], with the impact expected to persist until no sooner than 2024 IATA [18]. Gudmundsson et al.'s [19] research forecast a similar recovery path, with the ideal scenario occurring in mid-2022 and the most pessimistic scenario occurring in 2026. During the pandemic, it is critical to ascertain the satisfaction levels of internet customers' evaluations to ascertain their preferences for airline services. Online customer reviews are an invaluable resource for identifying the customer voice during an outbreak. Indeed, through online customer evaluations, the primary worries of customers may be easily discovered as well as their degree of satisfaction. As a result, new data analysis tools and methodologies for collecting and analyzing data from online consumer evaluations must be created. Hence, we believe that typical statistical methods based on survey-based data collecting would be ineffective in assessing consumer satisfaction during the COVID-19 pandemic.

The purpose of this study is to ascertain passengers' satisfaction with the top 10 airlines, as determined by TripAdvisor evaluations, during the COVID-19 pandemic. Additionally, we use UGC's big data, which includes textual information, to scientifically create and define satisfaction characteristics. Leximancer is used for large data analysis to recognize the voice of the airline passengers. TripAdvisor data were gathered on passengers' concerns expressed through online reviews during the COVID-19 pandemic. As a result, this research covers a research lacuna in the prior literature by integrating text mining and supervised machine learning approaches to conducting a qualitative content analysis of UGC. In general, our work makes the following contributions:

During the COVID-19 pandemic, we used a text mining method, Leximancer, to extract satisfaction dimensions from text-based internet evaluations. The Leximancer has been demonstrated to be useful in text-based reviews, particularly in airline research [2]. Identifying passenger's behaviors and complaints using UGC in tourism and hospitality is critical for improving service quality during a crisis, such as the COVID-19 pandemic [6]. Numerous studies have examined consumer satisfaction in the hospitality industry by establishing new approaches based on internet evaluations. However, this issue has received scant attention in the aftermath of a calamity, such as the COVID-19 pandemic.

This research advances the state of the art in the use of spontaneously created material to investigate customer satisfaction aspects. To our knowledge, this is the first attempt to utilize Leximancer to discover and extract customer satisfaction aspects using data from airline companies during the COVID-19 pandemic. While Leximancer is widely regarded as the primary tool for extracting prominent themes from unstructured texts [2], there is no indication that it was used to study passenger satisfaction in the airline business during the COVID-19 pandemic. 
Our study examined whether the dominant themes of passengers' overall experiences vary by traveler origin, which may give more insight into airline sector market segmentation. Hence, this study answers to Brochado et al.'s [2] call for studies to analyze passengers' overall experiences and how they relate to travelers' nationality.

\section{Literature Review}

\subsection{COVID-19 and Aviation Industry}

The COVID-19 pandemic has surpassed all previous pandemics, infecting over 200 countries and being supported in its spread by the aviation industry [14]. The COVID-19 virus has inflicted damage on an unprecedented scale on the world's airline industry $[15,16]$. Although the global aviation business was thriving, the COVID-19 epidemic has caused a serious impact on it. Global commercial aviation profit is anticipated to decline to 51.8 billion U.S. dollars in 2021, from 137.7 billion in 2020. The COVID-19 pandemic has grown to be the deadliest in aviation history [17], with the impact projected to last until no later than 2024, according to IATA [18]. Gudmundsson et al. [19] anticipated a similar recovery path, with the best-case scenario occurring in mid-2022 and the worst-case scenario occurring in 2026.

As highlighted above, the pandemic of COVID-19 has wreaked havoc on the tourism sector [20]. Air travel was key in the virus's initial spread, and virtually every country has closed its borders or imposed travel restrictions [21,22]. By August 2020, the number of scheduled airline flights globally will have fallen by 47.5 percent [2]. Since March 2020, the global aviation sector has seen passenger demand decline by $70 \%-95 \%$ [23]. To gain a better understanding of the COVID-19 pandemic's impact on the global aviation industry, a flood of research into the crisis's effects on the industry is necessary, if not critical, to support future operations [24]. Flying was a pleasurable and unusual experience for many individuals, as seen by impulsive purchasing within airports [21]. Airlines have responded to this sharp decline in demand by grounding substantial sections of their fleets and furloughing aircrews and support staff [21]. In addition, the stigma attached to COVID-19 is a result of a variety of reasons, including ignorance, insecurity, fear of responsibility, administrative failure, and a lack of faith in therapy [25]. These unpleasant feelings have a direct impact on the public's willingness and capacity to travel. Employers have placed limitations on employees' travel and social activities, threatening them with termination or unpaid leave if they do not adhere to the regulations. Individuals have been shunned by friends and family following activities, such as travel, that entail a significant risk of viral infection [21].

Despite the extensive research conducted in the hospitality sector during the COVID19 pandemic, relatively little research has been conducted on the aviation sector at the time of the pandemic. For example, Dube et al.'s [26] research analyzed COVID-19's influence on the worldwide aviation sector. The result of the study found that the pandemic had a tremendous toll on global aviation, resulting in ratings downgrades, liquidation, and bankruptcy of numerous airlines and airports because of the high cash burn caused by travel restrictions. Another research done by Liu et al. [15] reported that strong flying restrictions had a spontaneous effect on limiting the spread of COVID-19. Furthermore, the study sought to determine the role of aviation-related travel limitations in controlling the spread of COVID-19 throughout Europe. According to the study result, the airline sector canceled almost 795,000 flights during the shutdown. One recent study done by Abate et al. [27] examined government assistance measures for the airline industry in the aftermath of the coronavirus from two perspectives. Cited authors found that many governments place a premium on preserving air transport connections to safeguard economic activity and employment in aviation and associated industries, such as tourism. The trade-off between providing connection and preserving competitiveness in the aftermath of the COVID-19 pandemic is a complex political and economic issue. From the standpoint of aviation demand sustainability, Song and Choi [28] examined passenger opinions regarding whether Korean passengers will resume air travel following COVID-19. Cited authors 
found that individuals may contemplate resuming foreign air travel before the discovery of a COVID-19 treatment or vaccine corresponding to eased self-isolation criteria if the number of confirmed cases decreases. Using a sample of 639 reviews written on the website, Piccinelli et al.'s [29] study aimed to assess air travelers' concerns regarding the COVID19 pandemic. The cited authors found that passengers' concerns were sourced mainly towards compensations and cancellations. A study conducted by Lamb et al. [30] sought to investigate what type of passenger is willing to fly in the time of the pandemic. Findings revealed that in both business and pleasure travel, regression equations were developed, and the following variables were shown to be significant: perceived danger from COVID-19, agreeableness, affect, and fear. Another recent study done by Zhang et al. [31] collected air passenger-level data from TravelSky in the Chinese market. Their paper explored changes in airline passenger travel behavior, such as "ticket booking time," "age distribution of passengers," "refunds and ticket changes," and "passenger arrival time at airports."

As previously stated, the COVID-19 pandemic poses a significant barrier to the airline industry [20]. Despite extensive study on COVID-19 in the aviation domain, little is known about the service perception of passengers, particularly focusing on online reviews especially in the time of pandemic [29]. As a result, our study explored the service perception of passengers at the time of the COVID-19 pandemic. The research questions addressed were as follows: (1) What are the themes and associated concepts of airline experiences by passengers during the COVID-19 pandemic? (2) What are the themes most closely aligned with satisfaction and dissatisfaction regarding airline experiences during the COVID-19 pandemic? (3) What are the most dominant themes in terms of passengers' nationality when it comes to describing their airline experiences?

\subsection{Service Quality in the Airline Industry}

To retain their sustainability in today's difficult global competitive climate, to give competitive advantage, and to create a loyal customer base in the long term, airlines should be able to deliver quality service to their consumers continually. In other words, customer satisfaction is one of the key determinants of loyalty, which is crucial to the existence and sustainability of businesses [32]. The number of studies on airline service quality has increased rapidly since its link with customer satisfaction and productivity was identified [33]. Service quality is a complex of many contacts between passenger and airline personnel as well as anything else that may influence customers' views, such as an airline's image [34].

The extant service quality literature reveals that SERVQUAL measure is extensively used by many researchers to assess the quality of airline service [35-37]. Basfirinci and Mitra [36] evaluated airline service quality components in terms of their influence on customer satisfaction across cultures. Another study done by Elliott and Roach [38] determined that on-time luggage delivery, high-quality food services, luxurious seats, a smooth check-in process, and in-flight service features are crucial in the eyes of passengers. One research piece conducted by Truitt and Haynes [39] defined service quality in terms of the check-in procedure, transit appropriateness, luggage handling, promptness, seat hygiene, catering quality, and customer complaint behavior. Koklic et al. [40] found a strong positive relationship between customer satisfaction and quality of staff and airline tangibles (seat comfort, legroom, and extra offers) for full-service carriers.

Customers view comfortable seats and seat cleanliness as critical services that any aircraft company can provide [41,42]. Additionally, they demonstrated experimentally why the airline sector must provide a "complaint handling service" to passengers. Park [43] also reported that passengers, regardless of their history or origin, have their perceptions about seats, classes, and frequency of use. Additionally, customers place a premium on the airline industry's "safety-related services" [42]. Chen [44] stressed that to achieve a competitive edge and sustain growth in the aviation industry's highly competitive climate, businesses must deliver high-quality services to their passengers. According to Chen [44], 
several previous researches have indicated that service quality has a substantial effect on customer satisfaction or perceived value.

Park et al. [45] demonstrated in their study that the aviation sector has several service quality characteristics that are unique to the service industry and cannot be quantified using the SERVQUAL scale, such as ticketing, luggage allowance, and onboard facilities. Cronin and Taylor [46] developed the Service Performance (SERVPERF) scale to evaluate service quality more efficiently in the aviation sector; however, it has also come under fire from several researchers $[47,48]$. SERVPERF was criticized for its failure to track all facets of airline service quality performance. Along with the SERVQUAL and SERVPERF models, a 43-item AIRQUAL model was created [49]. Eight variables impacting the quality of airline service were identified in this scale because of a study performed with 583 customers of the state airline in Northern Cyprus. These aspects include airline and terminal physical features, staff, empathy, image, customer happiness, intent to purchase again, and word of mouth. In their research using the AIRQUAL model, Nadiri et al. [49] discovered that the dimension affecting service quality among these eight dimensions was the "physical components" dimension. However, the AIRQUAL model has been challenged for a variety of reasons, including the model's limited application to a single airline and geographical region and its scarcity in the literature in terms of application numbers; in other words, it has not gained broad adoption [50].

\subsection{User Generated Content in Airlines Research}

Online reviews have developed into major data sources for travelers, affecting up to $20-50 \%$ of online purchasing decisions [51]. Previous scholars have emphasized (see Table 1) the airline industry's ability to get actionable insights and knowledge about customers' experiences, feelings, interests, opinions, behaviors, satisfaction, and preferences through online reviews [2,3,29]. For instance, when compared to other information sources, social media sites, such as TripAdvisor, are seen as a more credible source of travel information [52]. Few numbers of studies are increasingly realizing that the airline passengers' online commentaries represent a rich vein of data for contributing to the analysis of passengers' experiences. Recent literature has identified both the influence of online user-generated content [53] and the valuable research possibilities inherent in examining them [2]. The present study follows this emerging style of work and redeploys the rich commentary data available on a major international review site, TripAdvisor, especially in the time of COVID-19. According to Pearce and Wu [54], the specific choice of TripAdvisor is considered in more detail in the Methods section in various works. In most examples, retrieving archival information from the internet is timesaving as well as economical. These reviews are appropriate to websites, posts made by tourists, and online societies [55]. Some of the applications of utilizing present online information contain passenger airline experience [56] as well as gauging the features that affect passengers' satisfaction with airline companies [3,57]. A review of these empirical studies advises that all the scholars have found utilizing online data to be an influential technique in generating natural as well as meticulous explanations about both overall and complex topics. In the web 2.0 era, scholars can take advantage of using efficient computer-based tools to summarize very large data sets [54].

The COVID-19 crisis's uncontrolled consequences compelled airline management to reimagine visitor experiences. Airline managers must be aware of the immediate and postpandemic consequences to implement appropriate management practices. Table 1 shows previous literature of studies focusing on online passengers' reviews in the airline industry. Apart from the research mentioned above (Table 1), we gathered data from TripAdvisor on passengers' views expressed through online reviews during the COVID-19 pandemic. As a result, this research addresses a research void in the prior literature by offering a qualitative analysis of UGC that incorporates text mining, clustering, and supervised machine learning approaches at moments of difficulty. 
Table 1. Summary of the selected past and recent studies using online reviews in the aviation industry.

\begin{tabular}{|c|c|c|c|c|}
\hline Authors & Online Review & Data Source & Statistical Approach & Main Findings \\
\hline Kwon et al. [58] & 14,000 & Skytrax & Latent Dirichlet allocation & $\begin{array}{l}\text { As a result of the topic modeling, "seat," "service," and "meal" were significant } \\
\text { issues in the flight through frequency analysis. Additionally, the result revealed that } \\
\text { delay was the main issue that can affect customer dissatisfaction, while "staff } \\
\text { service" can make customers satisfied through sentiment analysis, as the result } \\
\text { shows the "staff service" with meal and food in the topic modeling. }\end{array}$ \\
\hline Shadiyar et al. [59] & 1693 & Skytrax & UCINET 6.0 and CONCOR & $\begin{array}{l}\text { As a result, authors found dominant themes consist of "seat comfort," } \\
\text { "entertainment," "airlines and destination," "ground service," "food and beverage," } \\
\text { and "value for money." }\end{array}$ \\
\hline Korfiatis et al. [56] & 557,208 & TripAdvisor & $\begin{array}{l}\text { Structural Topic Models, and Latent } \\
\text { Dirichlet Allocation }\end{array}$ & $\begin{array}{l}\text { - Online reviews offer a solution through quality features extracted from review } \\
\text { text. } \\
\text { - } \quad \text { Using structural topic modeling, the review is coupled with numerical ratings. } \\
\text { - } \quad \text { An experimental application to airline passengers' reviews is revealed. }\end{array}$ \\
\hline Lim and Lee [60] & 11,031 & Skytrax & Latent Dirichlet allocation & $\begin{array}{l}\text { The results reveal that the most significant aspects for FSCs and LCCs are tangibles } \\
\text { and reliability, respectively. The least important characteristics are certainty and } \\
\text { empathy, respectively. By analyzing retrieved characteristics in-depth, we uncover } \\
\text { distinct variations in passenger impressions between FSCs and LCCs. }\end{array}$ \\
\hline Stamolampros et al. [62] & 557,208 & TripAdvisor & Structural Topic Modeling & $\begin{array}{l}\text { Eight specific aspects of the flight experience found: (1) legroom, (2) seat comfort, ( } 3 \text { ) } \\
\text { customer service, (4) value for money, (5) cleanliness, (6) check-in and boarding, (7) } \\
\text { food and beverage, and (8) inflight entertainment/wi-fi connectivity. }\end{array}$ \\
\hline Park et al. [63] & 157,035 & TripAdvisor & Tobit model & $\begin{array}{l}\text { The quality of certain service attributes, such as cleanliness, food and beverages, and } \\
\text { in-flight entertainment, affects the variations of positive ratings as a satisfier. Other } \\
\text { airline service attributes, such as customer service and check-in and boarding, } \\
\text { influence the deviations of negative ratings as a dissatisfier. }\end{array}$ \\
\hline
\end{tabular}


Table 1. Cont.

\begin{tabular}{|c|c|c|c|c|}
\hline Authors & Online Review & Data Source & Statistical Approach & Main Findings \\
\hline Sezgen et al. [3] & 5120 & TripAdvisor & Latent Semantic Analysis & $\begin{array}{l}\text { The findings indicate that the factors influencing passenger happiness vary } \\
\text { significantly depending on the class of air travel bought. For those traveling in } \\
\text { economy class, personnel friendliness and helpfulness are critical elements; for those } \\
\text { traveling in luxury cabins, product value is critical; and a cheap price is the primary } \\
\text { driver of happiness. }\end{array}$ \\
\hline Punel et al. [64] & 40,510 & Skytrax & Rpackage Sentiment Analysis & $\begin{array}{l}\text { However, the primary factor used to assess the entire flight experience is the cabin } \\
\text { staff service. Additionally, the data demonstrate that passenger expectations differ } \\
\text { between first or business class and economy class. First and business class } \\
\text { passengers are more concerned with seat comfort, food and beverage service, and } \\
\text { in-flight entertainment. Economy class passengers are more interested in value } \\
\text { for money. }\end{array}$ \\
\hline Xu et al. [65] & 2439 & Skytrax & SentiStrength software, LISREL 9.2 & $\begin{array}{l}\text { The findings indicate that the origins, size, and consequences of service failures } \\
\text { affect both positive and negative feelings among passengers. Compensation for the } \\
\text { present journey, whether monetary or nonmonetary, can help reduce unpleasant } \\
\text { feelings in passengers, but compensation for future travel has little effect } \\
\text { on emotions. }\end{array}$ \\
\hline Stamolampros et al. [66] & 380,000 & TripAdvisor & Latent Dirichlet allocation & $\begin{array}{l}\text { In the study, the authors explored how cultural factors affect the intensity of bias } \\
\text { using Hofstede's framework and find evidence for the moderating effect (both } \\
\text { positive and negative) of passengers' cultural dimensions on their supplied } \\
\text { evaluations of domestic carriers. }\end{array}$ \\
\hline Brochado et al. [2] & 1200 & TripAdvisor & Leximancer & $\begin{array}{l}\text { The analyses revealed nine themes in descriptions of airline travel experiences. } \\
\text { These are the core services during "flights," "airport" operations, crew and ground } \\
\text { "staff," ticket "classes," "seats," inflight "services," "entertainment," overall } \\
\text { experiences of "airlines," and post-purchase recommendations of with which } \\
\text { companies to "fly." Low value for money ratings is linked with the "airport" and } \\
\text { "flights" themes. }\end{array}$ \\
\hline
\end{tabular}




\section{Method}

\subsection{Data Collection}

The data for this study were obtained from TripAdvisor.com (accessed on 3 December 2021), a website that enables travelers to rate and review hotels, airlines, restaurants, and locations as well as voice their opinions [52]. TripAdvisor.com, a Boston-based firm formed in 2000, pioneered travel-related electronic word-of-mouth (e-WOM) [67] by enabling passengers to provide feedback (i.e., customer review) on their lodging experience for the first time. TripAdvisor is a game-changer in the travel and tourism industries and has grown to become the largest online travel guide in a few years [52], with 411 million monthly users browsing over 700 million travel reviews [68]. When selecting reviews to scrape, only those written in English were considered, and ones that were too brief were discarded. The longer reviews were favored in all situations [69]. We gathered online reviews from Azul, Singapore Airlines, Korean Air, Japan Airlines, Jet2.com (accessed on 3 December 2021), Air New Zealand, Eva Air, and Virgin Atlantic Airways. The reason justifying the choice of the aforesaid ten airlines is that those airlines were awarded as top ten airlines based on "TripAdvisor's Traveler's Choice 2020" ranking. "TripAdvisor's Traveler's Choice 2020" ranking based on millions of reviews and opinions from travelers from around the world; this annual award recognizes the very best tourism establishments in terms of service, quality, customer satisfaction, and more across a range of categories. In accordance with the study's objective, terms such as "COVID-19," "pandemic," and "virus" were entered to scan all TripAdvisor reviews, and other reviews were not taken into consideration. This data collection technique is favored in the study done by Davras and Durgun [70]. In total, 498 usable passenger reviews were taken into consideration for further analysis (Table 2). Judgmental sampling was used to ensure the number of reviews needed to use Leximancer software as well as to match the sample size of previous related studies. For instance, Chiu et al. [71] gathered 152 online reviews, Pearce and Wu [54] analyzed 167 reviews, and Rodrigues et al. [72] used 603 reviews. Judgmental sampling is a type of convenience sampling in which participants are selected at random from the accessible population. This sampling approach is appropriate when the population under study is difficult to identify or when some members are deemed more acceptable (knowledgeable, experienced, etc.) for the study than others [73]. Around 26.5 percent of the reviews were written by flyers from Asia, 26.3 percent from Europe, 25.1 percent from America, and 19.1 percent from Australia. In terms of gender, 64 percent males and 36 percent females (see Table 2 ) composed the dataset.

Table 2. Descriptive statistics for reviewers (number $=498)$.

\begin{tabular}{cccc}
\hline Variable & Category & Frequency & $\%$ \\
\hline Origin & Asia & 132 & 26.5 \\
& Europe & 146 & 29.3 \\
& America & 125 & 25.1 \\
& Australia & 95 & 19.1 \\
& Male & 319 & 64 \\
& Female & 179 & 36 \\
\hline
\end{tabular}

\subsection{Data Analysis}

The data collection represents passengers' airline experiences using the Leximancer text analytics program (version 5.0). This program is based on Bayesian statistical theory and assembles fragments of evidence that best represent what occurs in the texts under investigation [2]. Broadly speaking, the program creates a thesaurus and then uses a machine-learning algorithm to find the best thesaurus of words extracted from the text input, arranging them according to themes, and showing the results in a concept map [74]. Through a three-part procedure [75], this type of map enables analysts to acquire insights into and comprehension of natural language (Figure 1). The software extracted semantic 
pattern information that enabled us to identify the key concepts and themes underlying passenger airline experiences in a concept map composed of concepts-represented by grey dots-that are then grouped into themes-represented by colored spheres [76]. The theme colors signify the significance of each theme, with themes heat-mapped from hottest to coolest (i.e., red-orange is the "hottest" or most noticeable theme, and purple is the "coolest" or least connected theme). The brightness of a concept's label reflects its frequency in the text. The brighter a concept label, the more repeatedly the concept is founded in the script [77]. The Gaussian conceptual map is used for developing a model from data. Leximancer's "thesaurus" and "document-log" functions assist interpretation and deeper analysis [78].

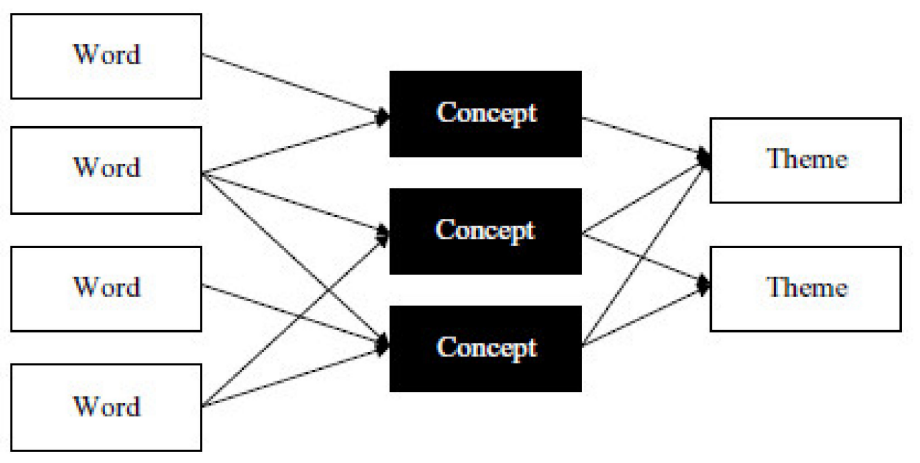

Figure 1. A basic model of semantic configuration extraction in Leximancer. Source: Adopted from Crofts and Bisman [75].

Hence, for the analysis, we used the Gaussian cluster algorithm of Leximancer and created concept clouds (see Figure 2). To get interpretable results from the analysis, extraneous grammatical particles, such as "an," "the," "as," and "I'm," were excluded. We then composed a data file for the numerical ratings corresponding to the two user-defined tags that correspond to two types of reviews, including "Rate: Excellent and Good," associated with positive experiences, and "Rate: Poor and Terrible," which were linked to negative experiences (see Figure 3).

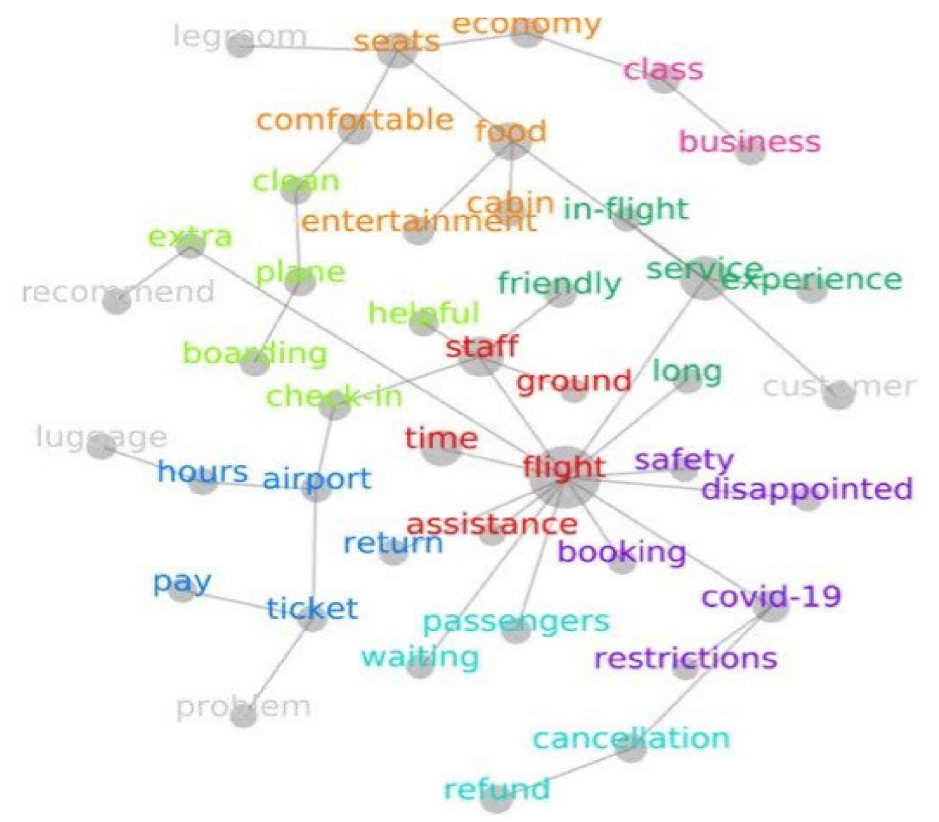

Figure 2. The Gaussian conceptual map. The theme colors signify the significance of each theme, with themes heat-mapped from hottest to coolest. 


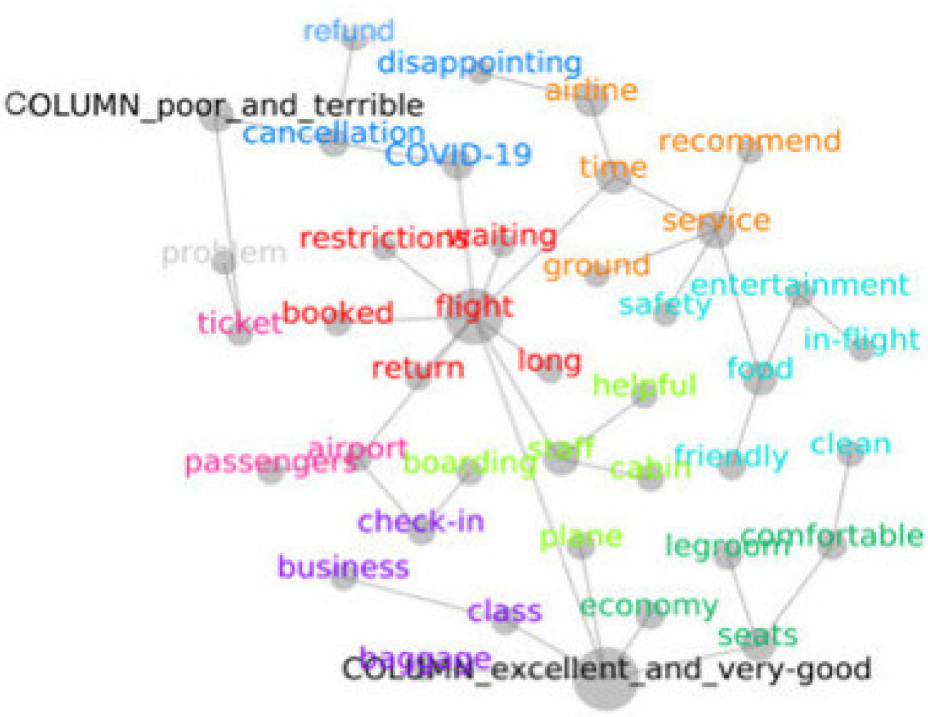

Figure 3. The Gaussian conceptual map for satisfaction characteristics used in customers' UGC for airline experience. The theme colors signify the significance of each theme, with themes heat-mapped from hottest to coolest.

Leximancer has also been used to research tourism and hospitality; for example, Pearce and $\mathrm{Wu}$ [54] used Leximancer to extract meaning from and analyze tourists' evaluation of a romantic-themed attraction. Tseng et al. [4] collected data from Chinese travel blogs to research destination images. Another recent study done by Arasli et al. [76] found key attributes of Muslim-friendly hotels' service quality using Leximancer. Brochado [79] researched nature-based experiences in tree houses focusing on guests' online reviews.

Leximancer is unique among content analysis tools. In contrast to NVivo or ATLAS, Leximancer does not employ a word-frequency analysis [4]. Concepts arise because of their frequency of recurrence, whereas the most prevalent concept emerges as the cluster's theme [80]. As the idea list generated by the program is derived from the text that we import, this solves the issue of reliability and validity [81]. An elevated level of reliability can help mitigate researcher bias and increase the repeatability of results, but inconsistencies in how coders classify material can undermine the reproducibility of coding results [82]. Attaining a high degree of reliability in human-coded content analysis is typically difficult and much more so when processing large amounts of data since this increases the likelihood of the researcher making an error in the phase of coding the themes [76]. Leximancer software was utilized to analyze the data. Numerous studies have also demonstrated that Leximancer software is reliable because it requires minimal manual intervention from the researcher and because it performs objective data analysis by removing researcher bias and coder subjectivity, which increases the validity of the results [83].

\section{Results}

The research questions addressed in this research were as follows: (1) What are the themes and associated concepts of airline experiences by passengers shared during the COVID-19 pandemic? (2) What are the themes most closely aligned with satisfaction and dissatisfaction regarding airline experiences during the COVID-19 pandemic? (3) What are the most dominant themes in terms of passengers' nationality when it comes to describing their airline experiences?

\subsection{General Description of Airline Travel Experiences in the Time of COVID-19}

To accomplish the study's first objective, a concept map was composed to identify the most often occurring themes and concepts in the evaluations of airline experiences of passengers during the COVID-19 pandemic as well as their frequency of recurrence and co-occurrence (see Figure 2). The Gaussian conceptual map depicts concepts (represented 
by tiny gray nodes) that are organized according to themes (indicated by the larger shaded circles), namely "flight," "service," "staff," "food," "check-in," "cancellation," "COVID-19," "airport," "class," and "luggage," based on online reviews. The connectivity rate for these 10 themes were $100 \%, 71 \%, 52 \%, 31 \%, 27 \%, 21 \%, 18 \%, 14 \%, 12 \%$, and $10 \%$, respectively. According to the aforesaid statement, ten major themes were found; each of these themes had a connection rate of more than $10 \%$. In the context of this research, the connectivity rate refers to the percentage of times that internal elements in the theme are referenced together [1,54]. It displays the relative prominence of themes (the most significant theme is at $100 \%$ ) [84]. The theme of flights contains the concepts of "time" and "safety." This first and most important dimension addresses the core services provided by airline companies during flights in the time of COVID-19.

"Thanks for your excellent customer service in this time of the pandemic. Gwen was able to address my concern on time. No questions were asked of why I was canceling my flight. Bravisssimo. Soon we'll flight again, you just became my favorite airline." Another passenger stated that "Everything went smoothly flying there and coming back with a stopover in Singapore. I never felt at risk of getting corona and am very grateful for their help." Another passenger shared, "When the COVID-19 outbreak started to impact flights, KAL was hopeless, totally hopeless. I wasted a week trying to resolve the flight changes." One review added, "a very COVID-19 safe experience as they handed out sanitation kits at the start of the flight."

The theme of services includes concepts such as "customer" and "in-flight" in the narratives of passengers. One flyer shared, "I can't rate Singapore Air any higher for their level of communication and customer service during the pandemic. We were due to fly on 23 October and the flight was canceled far enough in advance for us to consider alternative plans. Brilliant communication and full refund, including seats purchased, within a couple of days." Another passenger stated, "Amazing customer service, 2 phone calls from their office to keep me fully informed ... will 100\% book again!!" One review added, "From the comfort of the seating and overall space to the quality of the in-flight service, in terms of both food and drink and attention to detail given by cabin personnel, this was indeed a great experience and fully justified the expense of opting for Business Class on this very long flight."

The theme of staff included concepts such as "helpful," "friendly," and "ground," Some reviews shared by passengers mentioned both ground and cabin staff. An example review given about the staff is as follows: "Very professional, friendly, helpful flight attendants. We flew around the beginning of COVID-19 before new standards dealing with protection against the virus." Another review mentioned by the passenger stated, "My partner is paralyzed so I tend to have a lot to do with the staff on planes and so glad I did on this flight, they were incredibly friendly, and I think we could have been on the worst flight in the world and these staff would have made it better. We flew out on the 25 February so around the time the virus was kicking off the flight was empty, the pilot told us we could move into any row we wanted as there was a row free for each passenger and Air NZ have those amazing seats that fold out onto a bed so everyone was happy - this was also a night fighter and the staff were dead quiet to help everyone sleep, something you do not experience on many flights!. One passenger shared, "Had to get assistance with a wheelchair patient, and they could not do enough to help me, and made what seemed to be mission stress-free for us. The service by the ground staff at both airports was way beyond what I expected."

Another dominant theme that was found in the narratives of the passengers was food. A typical review shared by the passenger expressed that "The food was good and their attention to social distancing and COVID precautions was much appreciated. Highly recommend this flight." One review added, "I thought I had paid extra for all of us to have a meal but for some reason only my partner got the pre-paid meal, the staff gave the children food anyway. Highly recommend." Another review stated, "Great people on this flight and the one back. They were so lovely I told our lovely attendant that I liked the wine we had with dinner She promptly popped back with another bottle for me (the little ones). The plane was comfortable the food was delicious I could recommend JAL more highly."

The theme of check-in was another dominant theme that appeared in the narratives of passengers. An example review for this theme includes the following: "Priority boarding, 
disembarking and baggage retrieval worked very well. It certainly follows the very high-quality standard of Asian companies in which the customer is well served during the entire process, from check-in to baggage claim." Another passenger shared, "The whole experience was disappointing considering the high standard set by airline staff. The modern electronic check-in procedures before the flight were quite daunting especially when my passport was rejected." One review added, "Wonderful service on our trip out to New Zealand via Singapore, flight left and arrived on time, check-in was easy and smooth. Sadly, Singapore canceled their flights from Christchurch, NZ, before we were due to leave due to the pandemic and we're still waiting for a refund (2 months on)."

The theme of cancellation was another key theme found in passengers' reviews. Tourism-related activities have also been harmed by the pandemic. Recent viral transmission (with or without governmental quarantine efforts) resulted in a notable drop in what is referred to as "social consumption." Restricted activities include restaurant visits, domestic tourism, cultural events, and trade shows [85]. Numerous high-profile events have already been postponed or canceled in several nations. Due to many cancellations, the airline sector has nearly halved the number of flight plans [86]. Our analysis showed that the theme of cancellation is highly mentioned with the concept of refund. Typical reviews were shared regarding the cancellation: "We were, unfortunately, traveling during COVID-19. We were able to reach our destination (Auckland), but our flights back were canceled and the only info we got was a short email that the flight back (normally Auckland to Seoul, layover 2 days and Seoul to Frankfurt) will now start in Sydney and one day earlier." One review shared, "My family was supposed to fly to Japan next week, but we decided to cancel as there is currently a travel advisory for Japan (from Singapore) due to COVID-19. When we called JAL, they were very understanding and waived the cancellation fee." Still another review expressed, "Air NZ has canceled flights to New York, and we are now unable to visit our son. We emailed Air NZ and within 24 h we were advised that they were going to give us a full refund." One passenger shared, "I am very much depressed because I have not been getting my refund, I had saved for years to go for this trip and at the end, flight got canceled and I didn't get a refund, I do not know whom to complain, no one takes any action. It's been more than 7 months."

Another prominent theme that appeared in the reviews of the passenger was COVID19. The COVID-19 pandemic ushered in a wave of economic collapse around the globe owing to interruptions in the travel industry's supply and demand chains. The number of flights decreased dramatically, primarily because of measures implemented by governments to better respond to the COVID-19 pandemic, which included airport closures and measures affecting the tourism industry in general, such as the closure of borders and key regional and global tourist destinations worldwide. This occurred at a period when infection rates were also increasing [26]. Passengers used the COVID-19 theme together in their narratives with various concepts. Concepts that passengers used closely with the theme of COVID-19 were "restrictions," "cancellation," "refund," and "flight". A typical review shared by a passenger expressed, "When my flight was canceled due to COVID-19 flight restrictions-I received a courtesy call from JAL informing me of the cancellation and asking whether I'd like a full refund or credit. The refund was in my bank account within days." Another review shared, "Unfortunately, due to COVID, my flights have been canceled for 3 times by all different airlines (Singapore Airlines, Malaysia Airlines, and AirAsia). I have been waiting for the airlines to bring me home since April 2020." One flyer stated, "Singapore airline is a very shady company. They do not honor any refund when the flight was canceled due to COVID-19. They can't find our ticket or the charge after we have sent them copies of the credit statement and flight tickets. They won't let you swish to anyone in charge, they avoid all calls and when they want to get you off the phone. They say a check is in the mail it will take 9-10 weeks, but no check ever is mailed. Complete crooks!!!! Never book any flight with this company!!!.

A theme of the airport was another important theme that appeared in the reviews of the passenger. A typical review is as follows: "My flight was rescheduled a day earlier, and my connection flight forced me to stay in Japan airport for 2.5 days, and because of COVID-19, I couldn't get pass through the immigration and had to stay in the airport." Another review shared, "There were airport staffs walked you to the connecting flight as soon as you stepped out of the plane 
in Japan. Overall, it was a good experience traveling during COVID-19." One review posted, "We were paged several times in the airport but could not get to the gate any faster. There was no support or understanding from any of the ground staff or the flight staff." Furthermore, another traveler shared, "The staff at New Delhi airport is so rude and unprofessional. Korean Air should be ashamed of themselves for taking advantage of people during the panic of coronavirus."

The theme of classes included several concepts, such as business and economy. Typical reviews shared that "Singapore Airlines is a very good airline in the air. Their business class lounges in Singapore are terrible and fail dismally compared to other airlines' business class lounges." Another review shared, "The food came with plastic cover. They still tried to offer business class experience as best as they can during COVID-19." Another review shared, "The best time to travel during COVID-19, fewer travelers and the service on Business class was top!" One review posted, "The bottom line is it cost me \$124 to change dates for an economy class ticket. Their free date change is misleading and deceptive, but they get away with it."

The theme of luggage also appeared as a prevailing theme among passengers' reviews. A passenger wrote that "Boarding, disembarking and baggage retrieval worked very well. It certainly follows the very high-quality standard of Asian companies in which the customer is well served during the entire process, from check-in to baggage claim." Another review stated, "After spending over $3 \mathrm{~h}$ with the AC staff, he is still unable to locate it in Hong Kong and we had to file a missing baggage report. I left Hong Kong finally after $20 \mathrm{~h}$ without knowing the location of my bag and if it went on the same Cathay flight as me." One review posted, "It clearly says on their website we can have 2 check-in bags to Canada. But charged be \$300 for second check-in bag."

\subsection{Results of Satisfaction vs. Dissatisfaction Analysis}

The second research objective of this study was to determine whether passengers who rate their airline experiences as satisfactory (excellent and very good) or unsatisfactory (poor and terrible) use distinct descriptions in their narratives about their experiences and thus share distinct content in Web reviews during a pandemic. The analysis findings indicate that airline customers who rate airlines as 4 ("very good") or 5 ("excellent") shared narratives about flight, food, staff, and service (ground and in-flight). The most common concepts are related to the following: comfortable (97\%), cleanliness (96\%), seats (93\%), entertainment (92\%), and legroom (57\%). The second most likely focus is associated with personnel (88\%), which includes the concepts of ground (75\%), friendly(ness) (57\%), and helpful(ness) (51\%). Other themes, such as food (90\%), service (in-flight and ground) (87\%), and class (business and economy) (82\%), were closely associated with the tag of "very good" and "excellent," as depicted in Figure 3. In comparison, airline passengers who rate their airline experiences as dissatisfactory are more likely to share narratives regarding airline cancellations and refund processes due to COVID-19 and airport services. An assessment of the concepts associated with this group's reviews showed that the most repeatedly mentioned concepts are ticket (73\%), refund (57\%), disappointing (56\%), cancellation (54\%), booking (44\%), luggage (26\%), check-in (25\%), boarding (25\%), COVID-19 (25\%), waiting $(24 \%)$, and airport (22\%) (Figure 3).

Examples of negative reviews about the airline experiences focus on cancellations due to the COVID-19 pandemic, negative/late response from customer service of airlines, refund policy, and problems sourcing from airport services. One passenger wrote, "I'm not writing about the flight. I'm writing about customer service. My family of 11 was supposed to go to Brazil from Orlando. Our flight was canceled, kind of to be expected during this whole COVID-19 crap, but we had several moments of sheer panic. We called, and at no cost, they worked to get us all on the same flight from Fort Lauderdale to VCP. It was a pain in the butt I'm sure since we were all separate reservations. They did so with kindness and patience. You might say this should be expected, but in today's world, it's the exception to be sure. One guy I talked to, was EXTREMELY patient with a slight language barrier. I am utterly impressed. My wife is a contract M.D. and flies across the USA all the time and we have had some complete customer service nightmares, but not with AZUL. They got me praying for their success. Well done guys!!!" 
Another dissatisfied review shared, "I booked a flight for my husband and me for January 2022. It was part of a trip that involved the UK, USA, and cruising. It's now clear that this won't be possible due to COVID-19, so I canceled our flights. JAL processed my refund promptly but charged a $\$ 600$ cancellation fee. My understanding when I booked was that there would be no cancellation or change fees if the flights were canceled due to COVID-19 restrictions. I have tried unsuccessfully to get the rest of my refund via their Customer Service, so I can see that I will need to take my complaint higher. Other airlines have provided a full refund, so I hope JAL will do the right thing. I had put a travel date to submit this review but we have not yet traveled with JAL. And are not likely to do so unless they honor their free cancellation due to COVID commitment." One negative review added, "I'm a customer who is upset. I bought four return tickets (JL52) from Sydney-Tokyo (departure on 12 April 2020) through a travel agent called 'Qunar.' Due to the COVID situation, the flight was canceled, and a refund application was made on 28 March 2020. Over one year and a half, I spend time communicating with 'Qunar' about the update of this refund. Every time I had the same answer that Japan Airlines hasn't refunded yet and no information can be provided.' I understand there must be a large amount of application to deal with and I was patient. However, it has been one year and a half and I lose patience now. I'm here to confirm with you whether you have refunded but the agent kept the money, or the refund has not been dealt with. If not, I sincerely hope someone in this big company with a reputation fixes this problem. I, as a consumer, have no other way to protect my interest but hopefully, your company can be responsible." A further dissatisfied passenger added, "My understanding when I booked was that there would be no cancellation or change fees if the flights were canceled due to COVID-19 restrictions. I have tried unsuccessfully to get the rest of my refund via their Customer Service, so I can see that I will need to take my complaint higher." Another dissatisfied flyer stated, "Cracked a tennis racquet in oversized baggage. You would think oversized baggage means they handle it more carefully, though not. Tennis racquet cracked on the edge due to compression of some sort." One review shared from an unhappy traveler stated that "It seems pretty clear to me that this is COVID-19 related cancellation. The last thing I expected from JAL was a sleazy interpretation of what they advertise as 'free cancellation.'" One dissatisfied tourist shared, "I fully understand that it is difficult for airlines nowadays, so the long waiting time at customer service is still acceptable. But unfortunately, the service delivered was extremely disappointing, no client focuses and no knowledge about the airline details."

\subsection{Evaluation of the Airline Experience by Different Origins of Passengers}

The preceding subsections illustrate unequivocally that various travelers have varying attitudes regarding in-flight amenities. However, none of the studies used passenger country of residence to split the analysis to examine views and attitudes across different geographical locations. According to a related line of study, nationality affects customer behavior [64]. This part tackles objective three, which examines the flying experience of passengers from different origins. Thus, some studies have recommended that the origin of travelers should be examined [54] since each region is distinct. Chatterjee and Mandal [8] also believed that the origin might affect customer perception of quality.

The European passengers were found to be the most contradictory group and were either very critical about the flight or very happy with their experience, as depicted in Figure 4. Sixty-one percent of European tourists were likely to rate the flight experience as "excellent" and "very good." European tourists mainly shared narratives regarding concepts such as problem (56\%), a refund (49\%), restrictions (44\%), cancellations (39\%), and COVID-19 (35\%). Below are some typical but contrasting reviews from the European tourist group: 


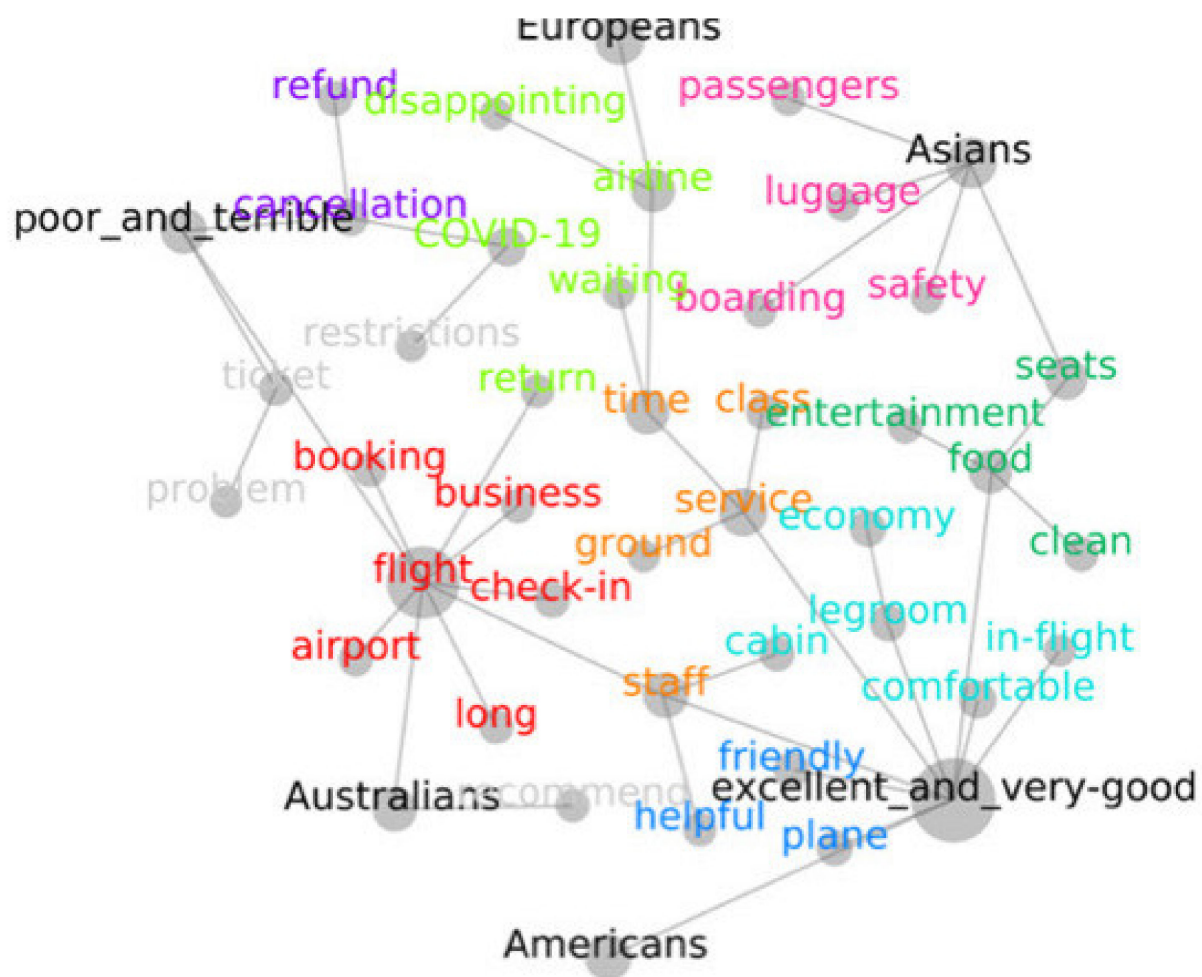

Figure 4. Different traveler-origin groups' evaluation of airline experience. The theme colors signify the significance of each theme, with themes heat-mapped from hottest to coolest.

"Due to very sad reasons I had to fly to the Netherlands/another side of the world unexpectedly during Corona. On booking, I called Singapore Airlines and this guy helped me patiently to get all the info I needed for flying during these times."

"My PCR came back positive under $24 \mathrm{~h}$ before my flight, and I thought my chances for flight change were very slim. To my surprise, Singapore Airlines offered a full refund!"

"The flights were quite empty due to the current government and travel restrictions, which meant that it was a very spacious and comfortable journey. I hadn't flown with JAL before, but I will consider flying with them again in the future!"

"Congratulations to Korean Air on their response to my cancellation due COVID-19. Original booking is done online in January 2020 for travel in September 2020."

Asian passengers were generally satisfied with the service provided by the airline services they experienced. They shared narratives in their reviews regarding in-flight (45\%), boarding $(44 \%)$, safety $(40 \%)$, cleanliness (38\%), luggage (36\%), and seats $(36 \%)$. They were very positive. Eighty percent of them were likely to rate the airline experience as "excellent" and "very good."

"I've flown on many carriers, but Korea Airlines is one of the best in the industry service and boarding process is seamless, meals are impeccable. The one drawback (if you want to call it that) is they do not have Wi-Fi."

"A very COVID-19 safe experience as they handed out sanitation kits at the start of the flight."

"Impressed by the service I got during my flight back from Phnom Penh to Jakarta via Singapore. I like their green and safe concept of in-flight meals."

"Legroom is very good at the bulkhead seat onboard Korean Air Economy Class as I was seated at the bulkhead, the tray table is stowed in the armrest of the seat. The bi-fold tray table is large enough to cover the entire width of the seat." 
Americans, a third group considered in the classification of visitor origins, were found to be one of the most positive groups in scoring the airline experience, with a likelihood of eighty percent of providing a "very good and "excellent" evaluation. Americans, in their narratives, mostly mentioned the concepts such as staff $(51 \%)$, friendly $(50 \%)$, helpful (49\%), and recommend(ation) (41\%). Typical comments shared by this origin are as follows:

"Putting it simply, they're superb. The staff and crew are supremely gracious, competent, and organized."

"Although they were extremely efficient, what most impressed me about them was their genuine commitment to looking after passengers from the heart. I strongly recommend Singapore Airlines and its amazing crews!"

"The crew are not only professionals but also clearly proud of their five-star reputation and it showed. I would recommend this flight; though I'd also point out that there is no other choice for a nonstop NYC-Singapore flight."

"Very professional, friendly, helpful flight attendants. We flew around the beginning of COVID-19 before new standards dealing with protection against the virus."

The last group considered in this study included Australian passengers. The Australians were also satisfied with the airline experiences with a likelihood of seventy-one percent of providing a "very good and "excellent" evaluation. Australians, in their narratives, mostly mentioned the concepts such as flight (41\%), airport (39\%), and check-in $(32 \%)$. Typical comments shared by this origin include the following:

"This was my first flight with Korean Air, and I was looking forward to an experience flying with them. I arrived at Incheon Airport after checking-in online hoping it would ease my dropping off luggage at the airport."

"I do hope the airline does reflect on the problems faced by travelers at check-in who are not their loyalty members of a higher tier. This will go a long way to making Korea Air, an airline of choice."

"This sparked a long wait as only a few counters out of all the counters at the airport handled such issues (joining the normal check-in line). The queue was slow, and I could have missed my flight if not for the kind assistance of a service supervisor I approach for help."

"Overall, I spent around $45 \mathrm{~h}$ flying with them in this period. The check-in was quick and easy, and the staff was friendly and helpful at all airports."

\section{Discussion and Conclusions}

\subsection{Conclusions}

The current study intended to accomplish three research objectives; the first of which was to uncover common patterns in online reports of airline experiences during the pandemic. Content analysis of a sample of UGC of the top ten airlines identified ten distinct themes: "flight," "service," "staff," "food," "check-in," "cancellation," "COVID-19," "airport," "class," and "luggage" were the most dominant themes representing passengers" flight experiences in the time of pandemic. The second research objective of this study was to determine whether passengers who rate their airline experiences as satisfactory (excellent and very good) or unsatisfactory (poor and terrible) use distinct descriptions in their narratives about their experiences and thus share distinct content in Web reviews during a pandemic. The analysis findings indicate that airline customers who rate airlines as 4 ("very good") or 5 ("excellent") are more likely to share narratives about "food", "staff" and" service" (ground and in-flight), "comfortable", "cleanliness", "seats", "entertainment", "legroom", "friendly(ness)", and "helpful(ness)", "food", and "class" (business and economy) as closely associated with the tag of "very good" and "excellent," as depicted in Figure 3. In comparison, airline passengers who rate their airline experiences as dissatisfactory are more likely to share narratives regarding airline cancellations and refund processes 
due to COVID-19 and airport services. An assessment of the concepts associated with this group's reviews showed that the most repeatedly mentioned concepts include "ticket", "refund", "disappointing", "cancellation", "booking", "luggage", "check-in", "boarding", "COVID-19", "waiting", and "airport". The third purpose of our study was to ascertain the most dominant themes expressed by passengers of various nationalities while discussing their airline experiences. The European passengers were found to be the most contradictory group and were either very critical about the flight or very happy with their experience. Sixty-one percent of European tourists were likely to rate the flight experience as "excellent" and "very good." European tourists mainly shared narratives regarding concepts such as "problem", "refund", "restrictions", "cancellations", and "COVID-19" in a negative tone.

\subsection{Discussion}

Defining customer satisfaction criteria is critical for correctly assessing how consumers rank airline services [2]. By incorporating spontaneous user-generated content (UGC), it is hoped to mitigate the biases associated with artificial replies provided by consumers in traditional research techniques, like questionnaire surveys [61]. The theme of flights is a dimension that covers the service quality element of airlines' core services identified by Lim and Tkaczynski [87]. This dimension mainly relates to overall travel experiences and flights' timeliness. This finding is consistent with the research done by Brochado et al. [2], who found the theme of the flight was the dominant theme according to travelers' narratives. In our study, the theme of the flight was mentioned together with safety. Our study's findings indicate that frequent fliers are concerned about their health and wellbeing considering the threat of infectious illnesses. Similar findings were published earlier this year in IATA's COVID-19 study, in which 78.3 percent of frequent flyer respondents expressed "very" to "moderately worry" about COVID-19 at all phases of the travel experience [88]. Additionally, a study done by Sotomayor-Castillo et al. [89] showed that health factors like pre-existing chronic diseases or being an older traveler have a significant impact on their degree of worry about COVID-19. Additionally, the findings of the cited authors demonstrated that passengers want their preferred airlines to do more to improve their health and safety and are willing to engage, requesting measures such as complimentary kits containing alcohol-based hand sanitizers, sanitary wipes, and face masks for all passengers as well as additional information on how to prevent and contain the risk of infection while flying.

In this study, the airline's onboard and ground staff are associated with topics such as employee qualities (e.g., friendly, and helpful). The theme of staff is mainly used in positive tones in the reviews shared by passengers. This finding is concordant with the research done by Brochado et al. [2] and Ban and Kim [53]. In parallel with our findings, research done by Sezgen et al. [3] also found that the theme of staff was one of the most dominant themes that appeared in the review of passengers, while the staff was the most common factor driving satisfaction for all passenger groups, in line with our finding.

Another dominant theme found in our study was food. Food and beverages play an important role in customer evaluations for airlines [90]. In our findings, food was mentioned in a positive tone among passengers. Our findings are consistent with the study conducted by Chatterjee et al. [91], who found strong positive sentiments about food and beverages. Focusing on the full-service airlines, Siering et al.'s [57] research found that food as an augmented service aspect is evaluated much more positively in the passengers' online reviews.

The theme of check-in was another dominant theme that appeared in the content of passengers. Check-in covers general service efficiency metrics, such as passenger waiting times linked to check-in and passport screening, operational efficiency, and service employees' attitudes [92,93]. Additionally, check-in is a critical procedure because it is the first operational step encountered by passengers during their travel [94]. In our study, the theme of check-in is mentioned in a negative tone in the reviews of passengers; this is due to long waiting hours at the airport. Taylor [95] found that a longer wait time may cause consumers 
to experience increased stress as a result of time loss and uncertainty. Larson et al. [96] reported that the longer passengers waited, the more likely they were to feel anxiety, wrath, irritation, discomfort, disappointment, demoralization, distress, and stress.

Another frequently mentioned theme among passengers in their airline experience was a cancellation. Liau and Tan [97] discovered using text mining that consumers of low-cost airlines (LCCs) had a negative perception of flight cancellations despite firms' attempts to appease them with monetary compensation. Due to many cancellations, the airline sector has nearly halved the number of flight plans [86]. Our analysis showed that the theme of cancellation is highly mentioned with the concept of refund. Given that companies initially omitted the refund option and, according to Forbes [98], some airlines were accused of actively concealing the steps required to obtain a cash refund, one can assume that the carriers' improper management of cancellations and related compensations (i.e., heavily advertising vouchers as a form of compensation for canceled flights rather than offering the refund option) resulted in incredible frustration. Furthermore, given that the Employment Expectations Indicator fell to its lowest level on record in April 2020 [99], those passengers may have felt the economic impact of the pandemic and had their income reduced because of reduced economic activity [100]; indeed, monetary compensation would be much appreciated. Concordant with our findings, Piccinelli et al.'s [29] research results showed that travelers' concerns were directed mainly towards compensations, cancellations, and COVID-19, and at the same time, they had mixed and unpredictable feelings.

The COVID-19 pandemic appeared as another dominant theme. This theme was the one with the most neutral ideas shared by passengers in their reviews. During the pandemic's peak period, airline customer service departments were inundated with calls from consumers seeking assistance, resulting in lengthy wait times [29]. A study done by Piccinelli et al. [29] focused on airline passenger's sentiment during the COVID-19. Their research also found similar findings concordant with our findings. Their study results reported that throughout the pandemic, the average sentiment score fluctuated between negative, neutral, and positive, with huge weekly swings. In addition, their study also showed that the sentiment scores related to cancellations, compensations, and customer service showed heterogeneous perceptions among consumers in the time of the pandemic. The COVID-19 pandemic ushered in a wave of economic collapse around the globe, owing to interruptions in the travel industry's supply and demand chains. The number of flights decreased dramatically, primarily because of measures implemented by governments to better respond to the COVID-19 pandemic, which included airport closures and measures affecting the tourism industry in general, such as the closure of borders and key regional and global tourist destinations worldwide. This occurred at a period when infection rates were also increasing [26]. This theme shared the experiences of passengers related to flight experience during the pandemic. As the number of COVID-19 instances grew, and subsequent travel prohibitions resulted in flight cancellations [101], prospective travelers' worries about boarding and on-time departures decreased, but concerns about cancellations increased.

Other substantial themes found in our study were the airport, class (first class, business class, premium economy, and economy class), and luggage. The theme of class is frequently used in the reviews of passengers, and both economy and business class concepts generally appeared in the positive reviews shared by passengers. Our findings regarding cabin class are concordant with the study done by Korfiatis et al. [56]. The cited authors found that cabin class (first class, business class, premium economy, and economy class) was mentioned positively in the reviews of passengers. On the other hand, airport and luggage were other dominant themes found in our research. The airport dimension described in this study encompasses both tangible assets and services (e.g., luggage, check-in, and gate). In parallel with our findings, studies done by Korfiatis et al. [56] and Brochado et al. [2] also found that airport and luggage are dominant themes and concepts shared by passengers in their online reviews. 


\subsection{Theoretical Implications}

Our paper adds to the existing knowledge base in the following ways. Firstly, a growing proportion of travelers use computerized customer reviews to assess the quality and performance of services [1]. On social media sites, these evaluations can have a significant influence on tourists' purchasing decisions. Electronic evaluations may be effectively used in conjunction with machine learning techniques to provide insights into passengers' decision-making processes and airline selection [2]. Although prior research on travelers' experiences has been extensively researched [7,102], this subject has received little attention in the context of a worldwide pandemic, such as the present COVID-19 issue [6]. Thus, this study sought to ascertain travelers' impressions of airlines using electronic reviews on TripAdvisor during the COVID-19 pandemic. Considering the aforesaid information, our research provides an insightful analysis of how travelers perceive airline services based on their internet reviews. Leximancer's analytical techniques aided the researcher in identifying the dominant themes underlying passengers' overall experiences in the time of the pandemic, some of which proved to be more significant than others.

Secondly, this study adds to the body of knowledge by identifying the major narrative motifs of passengers associated with positive and negative assessments. Indeed, the content analysis indicated that these two passenger segments use opposing descriptions in their narratives regarding airline experience, resulting in conflicting themes in the information shared online by the two segments.

Third, our study examined if the dominant themes of passengers' overall experiences vary by traveler origin, which may give more insight into airline sector market segmentation. Therefore, this study responds to the call of Brochado et al.'s [2] study that future research should examine the passengers' overall experiences vary according to travelers' nationality.

\subsection{Practical Implications}

The findings of this study offer airline industry executives a better understanding of how travelers evaluate airline service quality in the time of the COVID-19 pandemic, as evidenced by their Web evaluations. Understanding online reviews as a reflection of customers' experiences can assist airlines in identifying the primary characteristics necessary to promote good post-purchase behaviors and minimize negative intents [2] Thus, traveler evaluations not only enable airline businesses to obtain feedback from their customers at a low cost but also give them a chance to explore new ways to build positive post-purchase intents. To generate high passenger scores and positive eWOM, airlines should both provide effective customer calls as well as the refund policy and ensure service quality in-ground services in the airports in which they operate. More specifically, cancellation and refund orders increased significantly during the COVID-19 pandemic, but the online travel agency platforms' customer support systems were unable to keep up, leading to a considerable decrease in refund efficiency and a direct impact on the user experience. Reasonably diverting these orders is critical to resolving this issue. To avoid the same order occupying multiple service channels, platforms should enhance their software's usability [103], for example, by utilizing online self-service, human customer service, email, and other methods and associating them with distinct customers based on their identification number or product category. Additionally, redeploying personnel from other areas and hiring temporary customer support personnel can help alleviate strain on the customer service system [104]. Additionally, because physical aspects of airplanes (e.g., seating comfort) are regularly emphasized in passengers' narratives, these features represent another opportunity to enhance passengers' experiences. Charging cancellation fees was the most frequent issue that tourist consumers experienced throughout the refund procedure. Numerous complainants stated that associated authorities, tourism businesses, and airlines had proclaimed COVID-19 to be a force majeure, allowing customers to get a full refund if they canceled an order; consequently, these charges violated state regulations. Lastly, crises frequently necessitate excellent communication in addition to swift actions. 
Effective communication and explanation work is critical in comforting visitors during the refund process, and they both need a thorough and current grasp of pertinent rules as well as a proactive service attitude on the part of personnel. As a result, managers should bolster their enforcement of regulations through tight oversight and service quality management for staff during peak hours. However, it is important to recognize that employees have faced numerous psychological stresses because of health concerns, restricted living space, uncertain income, and changes in work arrangements and modes during the COVID19 pandemic. As a result, businesses also bear an obligation to support employees in sustaining healthy mental states [104].

\subsection{Limitation and Avenue for Further Research}

There are a few limitations to this research that need to be examined to determine future research areas. To begin, new study avenues might be identified by examining and comparing internet evaluations and textual views of visitors expressed in a variety of languages, places, and settings. Second, another study can compare online ratings and textual opinions of travelers for the same airline before and after the COVID-19 pandemic, which will provide useful results for airline managers in terms of contrasting which areas of passenger satisfaction have been impacted the most during this outbreak. Thirdly, the study focused only on data obtained from a single passenger platform. Another study might incorporate data from more portals, resulting in more generalizable findings. Fourth, electronic comments and ratings are dynamic in nature and evolve. Thus, to accommodate the changing requirements of travelers, future studies might examine techniques for incrementally investigating electronic views and evaluations. Fifth, the research focused exclusively on tourism and hospitality. Thus, extrapolating the outcomes of this study to other domains, particularly within the COVID-19 framework, is necessary, as the factors affecting customer satisfaction vary according to the kind of rated product or service.

Author Contributions: Conceptualization, D.S., M.B.S. and H.A.; methodology, D.S. and M.B.S.; software, M.B.S.; validation, H.A. and D.S.; formal analysis, M.B.S.; investigation, M.B.S.; resources, H.A.; data curation, D.S.; writing-original draft preparation, M.B.S. and D.S.; writing-review and editing, H.A. and M.B.S.; visualization, D.S.; supervision, H.A.; project administration, M.B.S.; funding acquisition, D.S. All authors have read and agreed to the published version of the manuscript.

Funding: This research received no external funding.

Institutional Review Board Statement: Not applicable.

Informed Consent Statement: Not applicable.

Data Availability Statement: Not applicable.

Conflicts of Interest: The authors declare no conflict of interest.

\section{References}

1. Arasli, H.; Saydam, M.; Kilic, H. Cruise Travelers' Service Perceptions: A Critical Content Analysis. Sustainability 2020, $12,6702$. [CrossRef]

2. Brochado, A.; Rita, P.; Oliveira, C.; Oliveira, F. Airline passengers' perceptions of service quality: Themes in online reviews. Int. J. Contemp. Hosp. Manag. 2019, 31, 855-873. [CrossRef]

3. Sezgen, E.; Mason, K.J.; Mayer, R. Voice of airline passenger: A text mining approach to understand customer satisfaction. J. Air Transp. Manag. 2019, 77, 65-74. [CrossRef]

4. Tseng, C.; Wu, B.; Morrison, A.M.; Zhang, J.; Chen, Y.-C. Travel blogs on China as a destination image formation agent: A qualitative analysis using Leximancer. Tour. Manag. 2015, 46, 347-358. [CrossRef]

5. Castillo-Manzano, J.I.; López-Valpuesta, L.; Sánchez-Braza, A. When the mall is in the airport: Measuring the effect of the airport mall on passengers' consumer behavior. J. Air Transp. Manag. 2018, 72, 32-38. [CrossRef]

6. Nilashi, M.; Abumalloh, R.A.; Alghamdi, A.; Minaei-Bidgoli, B.; Alsulami, A.A.; Thanoon, M.; Asadi, S.; Samad, S. What is the impact of service quality on customers' satisfaction during COVID-19 outbreak? New findings from online reviews analysis. Telemat. Inform. 2021, 64, 101693. [CrossRef] [PubMed]

7. Ahani, A.; Nilashi, M.; Ibrahim, O.; Sanzogni, L.; Weaven, S. Market segmentation and travel choice prediction in Spa hotels through TripAdvisor's online reviews. Int. J. Hosp. Manag. 2019, 80, 52-77. [CrossRef] 
8. Chatterjee, S.; Mandal, P. Traveler preferences from online reviews: Role of travel goals, class and culture. Tour. Manag. 2020, 80, 104108. [CrossRef]

9. Nilashi, M.; Ahani, A.; Esfahani, M.D.; Yadegaridehkordi, E.; Samad, S.; Ibrahim, O.; Sharef, N.M.; Akbari, E. Preference learning for eco-friendly hotels recommendation: A multi-criteria collaborative filtering approach. J. Clean. Prod. 2019, 215, 767-783. [CrossRef]

10. Jafari, K.; Özduran, A.; Saydam, M.B. Hospitality and tourism industry amid COVID-19 pandemic: Voices from small Mediterranean town. Int. Hosp. Rev. 2021. ahead-of-print. [CrossRef]

11. Cheer, J.M. Human flourishing, tourism transformation and COVID-19: A conceptual touchstone. Tour. Geogr. 2020, 22, 514-524. [CrossRef]

12. Karatepe, O.M.; Saydam, M.B.; Okumus, F. COVID-19, mental health problems, and their detrimental effects on hotel employees' propensity to be late for work, absenteeism, and life satisfaction. Curr. Issues Tour. 2021, 24, 934-951. [CrossRef]

13. Jafari, K.; Saydam, M.B.; Erkanlı, E.; Olorunsola, V.O. The impacts of the COVID-19 pandemic on the consumer behavior of Turkish tourists. Revista Turismo Estudos e Práticas-RTEP/UERN 2020, 5, 1-17.

14. Sun, X.; Wandelt, S.; Zhang, A. How did COVID-19 impact air transportation? A first peek through the lens of complex networks. J. Air Transp. Manag. 2020, 89, 101928. [CrossRef] [PubMed]

15. Liu, A.; Kim, Y.R.; O'Connell, J.F. COVID-19 and the aviation industry: The interrelationship between the spread of the COVID-19 pandemic and the frequency of flights on the EU market. Ann. Tour. Res. 2021, 91, 103298. [CrossRef]

16. IATA. Profit and Loss of Commercial Airlines Worldwide from 2010 to 2022, by Region (in Billion U.S. Dollars) [Graph]. In Statista, 5 October 2021. Available online: https:/ / www.statista.com/statistics/275603/profit-loss-of-commercial-airlines-worldwide/ (accessed on 24 December 2021).

17. Amankwah-Amoah, J. Note: Mayday, Mayday, Mayday! Responding to environmental shocks: Insights on global airlines' responses to COVID-19. Transp. Res. Part E Logist. Transp. Rev. 2020, 143, 102098. [CrossRef] [PubMed]

18. IATA, IATA Recovery Delayed as International Travel Remains Locked Down, 28 July 2020. Available online: https://www.iata $\mathrm{org} / \mathrm{en} / \mathrm{pressroom} / \mathrm{pr} / 2020-07-28-02 /$ (accessed on 19 October 2021).

19. Gudmundsson, S.; Cattaneo, M.; Redondi, R. Forecasting temporal world recovery in air transport markets in the presence of large economic shocks: The case of COVID-19. J. Air Transp. Manag. 2021, 91, 102007. [CrossRef]

20. Gössling, S. Risks, resilience, and pathways to sustainable aviation: A COVID-19 perspective. J. Air Transp. Manag. 2020, 89, 101933. [CrossRef] [PubMed]

21. Lamb, T.L.; Ruskin, K.J.; Rice, S.; Khorassani, L.; Winter, S.R.; Truong, D. A qualitative analysis of social and emotional perspectives of airline passengers during the COVID-19 pandemic. J. Air Transp. Manag. 2021, 94, 102079. [CrossRef]

22. Khatib, A.N.; Carvalho, A.-M.; Primavesi, R.; To, K.; Poirier, V. Navigating the risks of flying during COVID-19: A review for safe air travel. J. Travel Med. 2020, 27, 212. [CrossRef]

23. Whitely, S.; Philip, V.; Jasper, C.; Schlangestine, M.; Truong, A. How Corona-Virus Will Forever Change Airlines and the Way We Fly Bloomberg, Hyperdrive. 2020. Available online: https:/ / www.bloomberg.com/news / features/2020-04-24/coronavirustravel-covid-19-will-change-airlines-and-how-we-fly (accessed on 3 December 2021).

24. Tanrıverdi, G.; Bakır, M.; Merkert, R. What can we learn from the JATM literature for the future of aviation post Covid-19?-A bibliometric and visualization analysis. J. Air Transp. Manag. 2020, 89, 101916. [CrossRef]

25. Mahmud, A.; Islam, M.R. Social Stigma as a Barrier to Covid-19 Responses to Community Well-Being in Bangladesh. Int. J. Community Well Being 2021, 4, 315-321. [CrossRef]

26. Dube, K.; Nhamo, G.; Chikodzi, D. COVID-19 pandemic and prospects for recovery of the global aviation industry. J. Air Transp. Manag. 2021, 92, 102022. [CrossRef]

27. Abate, M.; Christidis, P.; Purwanto, A.J. Government support to airlines in the aftermath of the COVID-19 pandemic. J. Air Transp. Manag. 2020, 89, 101931. [CrossRef] [PubMed]

28. Song, K.-H.; Choi, S. A Study on the Behavioral Change of Passengers on Sustainable Air Transport After COVID-19. Sustainability 2020, 12, 9207. [CrossRef]

29. Piccinelli, S.; Moro, S.; Rita, P. Air-travelers' concerns emerging from online comments during the COVID-19 outbreak. Tour. Manag. 2021, 85, 104313. [CrossRef]

30. Lamb, T.L.; Winter, S.R.; Rice, S.; Ruskin, K.J.; Vaughn, A. Factors that predict passengers willingness to fly during and after the COVID-19 pandemic. J. Air Transp. Manag. 2020, 89, 101897. [CrossRef]

31. Zhang, L.; Yang, H.; Wang, K.; Bian, L.; Zhang, X. The impact of COVID-19 on airline passenger travel behavior: An exploratory analysis on the Chinese aviation market. J. Air Transp. Manag. 2021, 95, 102084. [CrossRef]

32. Özkul, E.; Bilgili, B.; Koç, E. The Influence of the color of light on the customers' perception of service quality and satisfaction in the restaurant. Color Res. Appl. 2020, 45, 1217-1240. [CrossRef]

33. Suki, N.M. Moderating Role of Gender in the Relationship between Hotel Service Quality Dimensions and Tourist Satisfaction. J. Qual. Assur. Hosp. Tour. 2014, 15, 44-62. [CrossRef]

34. Gursoy, D.; Chen, M.-H.; Kim, H.J. The US airlines relative positioning based on attributes of service quality. Tour. Manag. 2005, 26, 57-67. [CrossRef]

35. Huang, Y.K. The effect of airline service quality on passengers' behavioural intentions using SERVQUAL scores: A Taiwan case study. J. East. Asia Soc. Transp. Stud. 2010, 8, 2330-2343. 
36. Basfirinci, C.; Mitra, A. A cross cultural investigation of airlines service quality through integration of Servqual and the Kano model. J. Air Transp. Manag. 2015, 42, 239-248. [CrossRef]

37. Shah, F.T.; Syed, Z.; Imam, A.; Raza, A. The impact of airline service quality on passengers' behavioral intentions using passenger satisfaction as a mediator. J. Air Transp. Manag. 2020, 85, 101815. [CrossRef]

38. Elliott, K.; Roach, D. Service quality in the airline industry: Are carriers getting an unbiased evaluation from consumers? Serv. Mark. Q. 1993, 9, 71-82. [CrossRef]

39. Truitt, L.J.; Haynes, R. Evaluating service quality and productivity in the regional airline industry. Transp. J. 1994, $33,21-32$.

40. Koklic, M.K.; Kukar-Kinney, M.; Vegelj, S. An investigation of customer satisfaction with low-cost and full-service airline companies. J. Bus. Res. 2017, 80, 188-196. [CrossRef]

41. Chen, F.-Y.; Chang, Y.-H. Examining airline service quality from a process perspective. J. Air Transp. Manag. 2005, 11, 79-87. [CrossRef]

42. Liou, J.J.; Tzeng, G.-H. A non-additive model for evaluating airline service quality. J. Air Transp. Manag. 2007, 13, 131-138. [CrossRef]

43. Park, J.-W. Passenger perceptions of service quality: Korean and Australian case studies. J. Air Transp. Manag. 2007, 13, 238-242. [CrossRef]

44. Chen, C.-F. Investigating structural relationships between service quality, perceived value, satisfaction, and behavioral intentions for air passengers: Evidence from Taiwan. Transp. Res. Part A Policy Pract. 2008, 42, 709-717. [CrossRef]

45. Park, J.W.; Robertson, R.; Wu, C.L. Investigating the effects of airline service quality on airline image and passengers' future behavioural intentions: Findings from Australian international air passengers. J. Tour. Stud. 2005, 16, 2-11.

46. Cronin, J.J., Jr.; Taylor, S.A. SERVPERF versus SERVQUAL: Reconciling performance-based and perceptions-minus-expectations measurement of service quality. J. Mark. 1994, 58, 125-131. [CrossRef]

47. Ekinci, Y.; Riley, M. A critique of the issues and theoretical assumptions in service quality measurement in the lodging industry: Time to move the goal-posts? Int. J. Hosp. Manag. 1998, 17, 349-362. [CrossRef]

48. Babakus, E.; Boller, G.W. An empirical assessment of the SERVQUAL scale. J. Bus. Res. 1992, 24, 253-268. [CrossRef]

49. Nadiri, H.; Hussain, K.; Ekiz, E.H.; Erdoğan, Ş. An investigation on the factors influencing passengers' loyalty in the North Cyprus national airline. TQM J. 2008, 20, 265-280. [CrossRef]

50. Alotaibi, M.M. Evaluation of "AIRQUAL" Scale for Measuring Airlines Service Quality and its Effect on Customer Satisfaction and Loyalty. Ph.D. Thesis, Cranfield University, Cranfield, UK, 2015.

51. Mathwick, C.; Mosteller, J. Online reviewer engagement: A typology based on reviewer motivations. J. Serv. Res. 2017, 20, 204-218. [CrossRef]

52. Tsujioka, S.; Watanabe, K.; Tsukamoto, A. Tourism Analysis Using User-Generated Content: A Case Study of Foreign Tourists Visiting Japan on TripAdvisor. Tour. Sustain. Dev. Rev. 2020, 1, 57-64. [CrossRef]

53. Jovanović, T.; Božić, S.; Bodroža, B.; Stankov, U. Influence of users' psychosocial traits on Facebook travel-related behavior patterns. J. Vacat. Mark. 2019, 25, 252-263. [CrossRef]

54. Pearce, P.L.; Wu, M.Y. Tourists' evaluation of a romantic themed attraction: Expressive and instrumental issues. J. Travel Res. 2016, 55, 220-232. [CrossRef]

55. Lam, J.M.; Ismail, H.; Lee, S. From desktop to destination: User-generated content platforms, co-created online experiences, destination image and satisfaction. J. Destin. Mark. Manag. 2020, 18, 100490. [CrossRef]

56. Korfiatis, N.; Stamolampros, P.; Kourouthanassis, P.; Sagiadinos, V. Measuring service quality from unstructured data: A topic modeling application on airline passengers' online reviews. Expert Syst. Appl. 2019, 116, 472-486. [CrossRef]

57. Siering, M.; Deokar, A.V.; Janze, C. Disentangling consumer recommendations: Explaining and predicting airline recommendations based on online reviews. Decis. Support Syst. 2018, 107, 52-63. [CrossRef]

58. Kwon, H.-J.; Ban, H.-J.; Jun, J.-K.; Kim, H.-S. Topic Modeling and Sentiment Analysis of Online Review for Airlines. Information 2021, 12, 78. [CrossRef]

59. Shadiyar, A.; Ban, H.-J.; Kim, H.-S. Extracting Key Drivers of Air Passenger's Experience and Satisfaction through Online Review Analysis. Sustainainability 2020, 12, 9188. [CrossRef]

60. Lim, J.; Lee, H.C. Comparisons of service quality perceptions between full service carriers and low cost carriers in airline travel. Curr. Issues Tour. 2019, 23, 1261-1276. [CrossRef]

61. Lucini, F.R.; Tonetto, L.M.; Fogliatto, F.S.; Anzanello, M.J. Text mining approach to explore dimensions of airline customer satisfaction using online customer reviews. J. Air Transp. Manag. 2020, 83, 101760. [CrossRef]

62. Stamolampros, P.; Korfiatis, N.; Kourouthanassis, P.; Symitsi, E. Flying to Quality: Cultural Influences on Online Reviews. J. Travel Res. 2019, 58, 496-511. [CrossRef]

63. Park, S.; Lee, J.; Nicolau, J.L. Understanding the dynamics of the quality of airline service attributes: Satisfiers and dissatisfiers. Tour. Manag. 2020, 81, 104163. [CrossRef]

64. Punel, A.; Hassan, L.A.H.; Ermagun, A. Variations in airline passenger expectation of service quality across the globe. Tour. Manag. 2019, 75, 491-508. [CrossRef]

65. Xu, X.; Liu, W.; Gursoy, D. The Impacts of Service Failure and Recovery Efforts on Airline Customers' Emotions and Satisfaction. J. Travel Res. 2018, 58, 1034-1051. [CrossRef] 
66. Stamolampros, P.; Dousios, D.; Korfiatis, N. Evaluating domestic bias on airline passengers' ratings: The moderating effect of cultural value orientation. Int. J. Hosp. Manag. 2020, 87, 102466. [CrossRef]

67. Litvin, S.W.; Goldsmith, R.E.; Pan, B. A retrospective view of electronic word-of-mouth in hospitality and tourism management. Int. J. Contemp. Hosp. Manag. 2018, 30, 313-325. [CrossRef]

68. Gretzel, U.; Yoo, K.H. Use and Impact of Online Travel Reviews. Inf. Commun. Tech. Tour. 2008, 1, 35-46.

69. Cassar, M.L.; Caruana, A.; Konietzny, J. Wine and satisfaction with fine dining restaurants: An analysis of tourist experiences from user generated content on TripAdvisor. J. Wine Res. 2020, 31, 85-100. [CrossRef]

70. Davras, O.; Durgun, S. Evaluation of precautionary measures taken for COVID-19 in the hospitality industry during pandemic. J. Qual. Assur. Hosp. Tour. 2021, 1-23. [CrossRef]

71. Chiu, W.; Bae, J.-S.; Won, D. The experience of watching baseball games in Korea: An analysis of user-generated content on social media using Leximancer. J. Sport Tour. 2016, 21, 33-47. [CrossRef]

72. Rodrigues, H.; Brochado, A.; Troilo, M.; Mohsin, A. Mirror, mirror on the wall, who's the fairest of them all? A critical content analysis on medical tourism. Tour. Manag. Perspect. 2017, 24, 16-25. [CrossRef]

73. Altinay, L.; Paraskevas, A.; Jang, S.S. Planning Research in Hospitality and Tourism; Routledge: Abingdon-on-Thames, UK, 2015.

74. Arasli, H.; Furunes, T.; Jafari, K.; Saydam, M.B.; Degirmencioglu, Z. Hearing the Voices of Wingless Angels: A Critical Content Analysis of Nurses' COVID-19 Experiences. Int. J. Environ. Res. Public Health 2020, 17, 8484. [CrossRef]

75. Crofts, K.; Bisman, J. Interrogating accountability: An illustration of the use of Leximancer software for qualitative data analysis. Qual. Res. Acc. Manag. 2020, 7, 180-207. [CrossRef]

76. Arasli, H.; Saydam, M.B.; Gunay, T.; Jafari, K. Key attributes of Muslim-friendly hotels' service quality: Voices from booking.com. J. Islam. Mark. 2021. ahead-of-print. [CrossRef]

77. Wilk, V.; Soutar, G.N.; Harrigan, P. Tackling social media data analysis: Comparing and contrasting QSR NVivo and Leximancer. Qual. Mark. Res. Int. J. 2019, 22, 94-113. [CrossRef]

78. Kobayashi, K.; Fisher, R.; Gapp, R. Using computer-aided lexical analysis in management research. In Proceedings of the British Academy of Management, Belfast, British Academy of Management Conference Proceedings, Belfast, Ireland, 12-14 September 2006.

79. Brochado, A. Nature-based experiences in tree houses: Guests' online reviews. Tour. Rev. 2019, 74, 310-326. [CrossRef]

80. Dambo, T.H.; Ersoy, M.; Auwal, A.M.; Olorunsola, V.O.; Saydam, M.B. Office of the citizen: A qualitative analysis of Twitter activity during the Lekki shooting in Nigeria's \#EndSARS protests. Inf. Commun. Soc. 2021, 1-18. [CrossRef]

81. Dambo, T.H.; Ersoy, M.; Auwal, A.M.; Olorunsola, V.O.; Olonode, A.; Arikewuyo, A.O.; Joseph, A. Nigeria's\# EndSARS movement and its implication on online protests in Africa's most populous country. J. Public Aff. 2020, e2583. [CrossRef]

82. Krippendorff, K. Content Analysis: An Introduction to Its Methodology, 2nd ed.; Sage: Thousand Oaks, CA, USA, 2004.

83. Sotiriadou, P.; Brouwers, J.; Le, T.-A. Choosing a qualitative data analysis tool: A comparison of NVivo and Leximancer. Ann. Leis. Res. 2014, 17, 218-234. [CrossRef]

84. Brochado, A.; Brochado, F. What makes a glamping experience great? J. Hosp. Tour. Technol. 2019, 10, 15-27. [CrossRef]

85. Hoque, A.; Shikha, F.A.; Hasanat, M.W.; Arif, I.; Hamid, A.B.A. The effect of Coronavirus (COVID-19) in the tourism industry in China. Asian J. Multidiscip. Stud. 2020, 3, 52-58.

86. Uğur, N.G.; Akbıyık, A. Impacts of COVID-19 on global tourism industry: A cross-regional comparison. Tour. Manag. Perspect. 2020, 36, 100744. [CrossRef]

87. Lim, S.S.; Tkaczynski, A. Origin and money matter: The airline service quality expectations of international students. J. Hosp. Tour. Manag. 2017, 31, 244-252. [CrossRef]

88. IATA. IATA COVID-19 Passenger Survey. 2020. Available online: https://www.iata.org/en/publications/store/covid-passengersurvey/ (accessed on 21 May 2021)

89. Sotomayor-Castillo, C.; Radford, K.; Li, C.; Nahidi, S.; Shaban, R.Z. Air travel in a COVID-19 world: Commercial airline passengers' health concerns and attitudes towards infection prevention and disease control measures. Infect. Dis. Heal. 2021, 26, 110-117. [CrossRef]

90. Han, H.; Lee, K.-S.; Chua, B.-L.; Lee, S.; Kim, W. Role of airline food quality, price reasonableness, image, satisfaction, and attachment in building re-flying intention. Int. J. Hosp. Manag. 2019, 80, 91-100. [CrossRef]

91. Chatterjee, S.; Mukherjee, S.; Datta, B. Influence of prior reviews about a firm and its alliance partners on reviewers' feedback: Evidence from the airline industry. J. Serv. Theory Pract. 2021, 31, 423-449. [CrossRef]

92. Chonsalasin, D.; Jomnonkwao, S.; Ratanavaraha, V. Key Determinants of Airline Loyalty Modeling in Thailand. Sustainability 2020, 12, 4165. [CrossRef]

93. Bezerra, G.C.L.; Gomes, C.F. Measuring airport service quality: A multidimensional approach. J. Air Transp. Manag. 2016, 53, 85-93. [CrossRef]

94. Di Pietro, L.; Mugion, R.G.; Musella, F.; Renzi, M.F.; Vicard, P. Monitoring an airport check-in process by using Bayesian networks. Transp. Res. Part A Policy Pract. 2017, 106, 235-247. [CrossRef]

95. Taylor, S. Waiting for service: The relationship between delays and evaluations of service. J. Mark. 1994, 58, 56-69. [CrossRef]

96. Larson, R.C.; Larson, B.M.; Katz, K.L. Prescription for waiting-in line blues: Entertain, enlighten and engage. Sloan Manag. Rev. $1991,32,44-55$. 
97. Liau, B.Y.; Tan, P.P. Gaining customer knowledge in low cost airlines through text mining. Ind. Manag. Data Syst. 2014, 114, 1344-1359. [CrossRef]

98. Forbes Airlines Offer Discounts and Bonuses If Passengers Take Vouchers Instead of Refunds During Coronavirus Downturn, 25 March 2020. Available online: https: / / bit.ly/3tFlQM9 (accessed on 9 February 2021).

99. Directorate-General Financial and Economic Affairs of the European Commission Business and consumer survey results for April 2020 . 2020. Available online: https:/ / ec.europa.eu/info/sites/info/files/full_bcs_2020_04_en.pdf (accessed on 20 June 2020).

100. Commission Recommendation (EU) 2020/648 of 13 May 2020 on vouchers offered to passengers and travellers as an alternative to reimbursement for cancelled package travel and transport services in the context of the COVID-19 pandemic. Available online: http:/ / data.europa.eu/eli / reco/2020/648/oj (accessed on 13 June 2020).

101. Chinazzi, M.; Davis, J.T.; Ajelli, M.; Gioannini, C.; Litvinova, M.; Merler, S.; Piontti, Y.; Pastore, A.; Mu, K.; Rossi, L.; et al. The Effect of Travel Restrictions on the Spread of the 2019 Novel Coronavirus (Covid-19) Outbreak. Science 2020, 368, 395-400. [CrossRef]

102. Yadegaridehkordi, E.; Nilashi, M.; Nasir, M.H.N.B.M.; Momtazi, S.; Samad, S.; Supriyanto, E.; Ghabban, F. Customers segmentation in eco-friendly hotels using multi-criteria and machine learning techniques. Technol. Soc. 2021, 65, 101528. [CrossRef]

103. Navarro-Ruiz, S.; McKercher, B. The usability of visitor attractions: State-of-the-art. Tour. Rev. 2020, 75, 497-509. [CrossRef]

104. Lin, Y.H.; Chen, C.F. Passengers' shopping motivations and commercial activities at airports-The moderating effects of time pressure and impulse buying tendency. Tour. Manag. 2013, 36, 426-434. [CrossRef] 